\title{
Evaluation of CBR Characteristics of Waste Dust from Construction Debris as Pavement Material
}

\author{
Md. Murad Hasan 1, *, Mehejabin Chowdhury Ankan², Md. Ebrahim Shaik ${ }^{3}$ \\ ${ }^{1}$ Western Bangladesh Bridge Improvement Project (WBBIP), Oriental Consultant Global (OCG) Limited, Jashore, Bangladesh \\ ${ }^{2}$ Western Bangladesh Bridge Improvement Project (WBBIP), Jashore, Bangladesh \\ ${ }^{3}$ Department of Civil Engineering, Northern University of Business \& Technology, Khulna, Bangladesh
}

Email address:

muradhasan.ce@gmail.com (Md. M. Hasan), mehjabinankan@gmail.com (M. C. Ankan), ebrahimkuet82@gmail.com (Md. E. Shaik)

${ }^{*}$ Corresponding author

\section{To cite this article:}

Md. Murad Hasan, Mehejabin Chowdhury Ankan, Md. Ebrahim Shaik. Evaluation of CBR Characteristics of Waste Dust from Construction Debris as Pavement Material. Landscape Architecture and Regional Planning. Vol. 5, No. 1, 2020, pp. 12-20.

doi: $10.11648 /$ j.larp.20200501.12

Received: December 2, 2019; Accepted: December 17, 2019; Published: May 28, 2020

\begin{abstract}
In this study an attempt is made to investigate the properties and CBR characteristics of fine sand and waste dust from construction debris. Attempts are also made to study the effect of soaking period on CBR value of waste dust from construction debris. Waste dusts passing through $600 \mu \mathrm{m}$ sieve from construction debris and river sand are selected for investigation. Standard Test procedures specified by AASHTO are followed in this investigation. The testing includes the determination of specific gravity, sieve analysis, optimum moisture content, dry density and CBR value. Dense unit weight, specific gravity and fineness modulus of construction debris is $1273.44 \mathrm{Kg} / \mathrm{m}^{3}, 2.43$ and 1.36 respectively and for fine sand $1132.25 \mathrm{Kg} / \mathrm{m}^{3}, 2.62$ and 1.64 respectively. Un-soaked CBR value of construction debris and fine sand are $10.36 \%$ and $12.5 \%$ respectively. Soaked CBR values of construction debris and fine sand are $5.36 \%$ and $6.07 \%$ respectively. The study reveals that waste dust from construction debris is as good as fine sand for construction of sub-grade from the stand point of properties and CBR characteristics.
\end{abstract}

Keywords: CBR, Construction Debris, Fine Sand, Socked, Un-soaked

\section{Introduction}

The recycled waste materials are usually generated from Construction and Demolition (C\&D) or mercantile and industrial works. C\&D materials are surplus or squander components connected to the construction and destruction of roads and buildings, such as concrete, brick, salvaged asphalt, steel, wood, plastics as well as other construction materials and goods. Concrete waste is a by-product which is generated from demolition operation of concrete structure. Based on the implementation in the field, these concrete pieces are squashed into aggregates of differential dimensions. Reclaimed asphalt pavement (RAP) is the label given to asphalt at the time of dismantling of roadway, and these recycled wastes (RAP) are thrown into trash without applying any viable method for reuse [1].

The important research in the recycled construction waste has been examined how the technical characteristics like California Bearing Ratio (CBR), moisture content, compaction efficiency affected the construction quality, when recycled construction and demolition waste (CDW) are being used in pavement construction [6].

Construction wastes are usually described as the debris from demolished buildings and pavements. In recent time, a worldwide concern has emerged regarding recycling and reuse of construction elements, and statistics shown that quantity of waste material is raised continuously [2].

Reuse of waste dust form construction relics has long been established as a potential method to save natural resources and abate the power used during its manufacture. The substitution of traditional aggregates with recycled aggregates, in whole or in part, has been and is being examined in many trials. Recycled aggregates are being used to replace local materials in various phases, such as pavement 
construction, marine foundations, building construction, structural concrete or non-structural concrete [3].

The production of non-decaying waste materials in association with a rising number of users has led to a global hazardous waste crisis. Conversion of recycling waste into commercial products by applying suitable process can be a solution to overcome the recession. Hence, research on creative use of waste elements is regularly proceeding. There are lot of private companies, government organizations relevant to pavement construction is trying to check the possibility, affectivity and performance of recycled materials in pavement construction. These practices are focusing to meet the local demand for healthy disposal of waste material and requirement of highway construction trades for costeffective construction [4].

Though Construction and Demolition (C\&D) waste is one of the vital reasons of environment pollution, the reuse of such salvage materials can be cost effective and easily available in ample quantity in pavement construction. European countries like Netherland and Denmark has been implementing reuse of recycled waste in pavement

construction, and the utilizing rate is above 94\% [5]. Reuse of waste dust from construction salvage is very common in Netherlands, and sustainable improvement of road construction activities is the primary objective to recycling of the waste disposal [6].

Recently reuse of waste material in construction sector has got worldwide preference [7]. The origination of Construction and demolition waste (CDW) debris is raised remarkably in recent years, and it affects on environment adversely due to its improper management system. Recycling of these debris materials becomes the great concern to mitigate the nocuous effect on environment and objective of sustainable prosperity [16].

There are few methods to enhance the engineering behavior of material to make more effective for construction. Application of waste dust from construction debris either in mix with binder such as cement, lime etc. or without mixing with any ingredients is one of them [8].

Research on recycling of construction waste material ensure that reuse of these elements have high potentiality as aggregate in pavement construction. The aggregate from construction material is remarkable alternative material for base and sub-base course in road construction due to its high level of resistance and non-expansive property. Therefore, the quality of these recycled materials varies and a bit tough to control the quality, but few proper measures needed during process and application to pursue desire outcome [10]. Recycled materials derived from construction debris can be used as replacement of virgin aggregate in the pavement layer construction of highway as unbound material [3].

\section{Literature Review}

Extensive research relevant to properties and act of recycled materials is not available in the literature. The study on mechanical properties of reused construction waste material is quite easy and flexible process to justify the effectiveness in road construction. Barbudo, et. al., conducted a research to focus the possible co-relation between various ingredients of recycled aggregates and their mechanical properties for implementing in pavement construction. In this regard, they studied on 31 types of various aggregate, where four types were natural and another twenty seven types were generated from different eleven treatment plants. Finally the sample were taken into test (C. B. R.), Modified Proctor, Los Angeles coefficient) to find out mechanical properties. Then the result was justified with standard statistical tests ANOVA and linear correlation analysis (both simple and multiple) [3]. On-site recycling of construction debris as the pavement construction material reduces the transportation expenses [12]. Arulrajah, A., et. al., conducted another extensive laboratory analysis of the geotechnical and geo-environmental characteristics, where five construction waste materials were taken into count for research. The Construction and Demolition (C\&D) elements checked were recycled concrete aggregate (RCA), crushed brick (CB), waste rock (WR), reclaimed asphalt pavement (RAP), and fine recycled glass (FRG). California bearing ratio (CBR), water absorption, particle size distribution, particle density, compaction, Los Angeles abrasion, flakiness index, and hydraulic conductivity and post compaction sieve analysis tests were included in the assessment of geotechnical. A triaxial test was performed, which revealed the shear strength characteristics of the sample. Drained cohesion value from 41 $\mathrm{kPa}$ to $46 \mathrm{kPa}$ and drained friction angle ranging from $49^{\circ}$ to $51^{\circ}$ were found after performing consolidated drained triaxial tests of reused materials [1]. There are few difficulties still remain to recycle construction and demolition waste (CDW) including shortage of confidence of stakeholders, doubtfulness of environmental favor, distance between waste sites and treatment plant of recycling etc., though recycling is the most efficient way to control CDW [13].

The investigation was performed aiming recycling the construction waste as the major ingredients in flexible pavement construction. To check the quality of performance of material, sample was undertaken in laboratory test [4]. Reusing of construction and demolition waste material is vital technique to promote the sustainable improvement of the globe. The process reduces the transit and production cost, as well as requirement of the fresh construction material [14].

Gobieanandh, V., \& Jayakody, S., examined a research on waste from construction debris to analysis the feasibility as recycled material in base or sub base road construction, as well as explained the impact in pavement construction if recycled construction and demolition (C\&D) aggregate is mixed with traditional aggregates [5]. Few strategies are applied in Europe for recycling of C\&D waste aggregate intending to lessen execution of fresh aggregate in construction activities and to alleviate the adverse environmental effect on construction business [15].

An experiment was conducted to check the technical durability of construction debris as material for pavement layers construction of highway. In this regard, efficiency of pavement composed concrete, ceramic waste aggregate and 
asphalt mix was checked through a field research [6].

Vegas, I., et. al., conducted an investigation to explain the experimental process used and reveal the analysis for implementing technical methods regarding utilizing of recycling of construction waste in pavement construction. The methodology of investigation was generated from previous study relevant to the research [7]. Recycled construction material usually two types, one generates from crushed concrete named Recycled Concrete Aggregate (RCA) and another one is from construction and demolition waste (CDW). In Recent times lot of research have been done on both type of aggregates. Recycling of waste material rescued the environment from undesirable pollution; simultaneously these wastage materials are recycled [17].

A research showed the affects of waste dust on, California bearing ratio (CBR), unconfined compressive strength, liquid limit, shear strength parameters, plastic limit, compaction characteristics, plasticity index, and swelling pressure of an extensive soil [8]. A study on the analysis of quality and strength of the concrete that is produced from recycled waste material from various sources. In this regard, rejected waste material was collected from precast industries and concrete fabricated in laboratory were utilized [9]. Application of recycling construction debris instead of fresh virgin concrete assists to alleviate the landfill pressures and promotes the environment quality [18].

A research was conducted to analysis the possibility of reuse of waste in pavement construction generated from construction and demolition. Bearing capacity test and repeated triaxial test were done in a laboratory, which conducted by geotechnical characterization. The study revealed that the composition and the compactive effect on the physical characteristics of the recycled aggregate [10]. Recycled waste material is used in pavement construction effectively. Fly ash, tire chips and wood chips are the most significant waste item to be used as recycled material in road construction [11].

\section{Materials and Investigations}

\subsection{Materials}

A sub grade soil is normally composed of sand, silt and clay. The sands are generally divided into coarse, moderately coarse and fine fraction according to the size of individual particles. The following sections include the description of sand, clay and sandy clay mix used in this study.

\subsubsection{Fine Sand}

The friction of soil lies between $1.60 \mathrm{~mm}$ and $0.075 \mathrm{~mm}$ size is called fine sand. Dhopa-ghata river sand from Jhenaidah, Bangladesh was used as the source of fine sand (Figure 1). The physical appearance of that sand is shown in Figure 2.

\subsubsection{Construction Debris}

Construction and demolition (C\&D) debris is nonhazardous, uncontaminated material resulting from construction, remodeling, repair, or demolition of utilities, structures, and roads. Construction debris was collected from construction site of extension of Barda base camp (WBBIP project), Jhenaidah, Bangladesh. Construction debris was sieved by $600 \mu \mathrm{m}$ sieve to separate the larger particles. The physical appearance of construction debris and construction debris after passing through $600 \mu \mathrm{m}$ sieve is shown in Figure 3 and Figure 4 respectively.

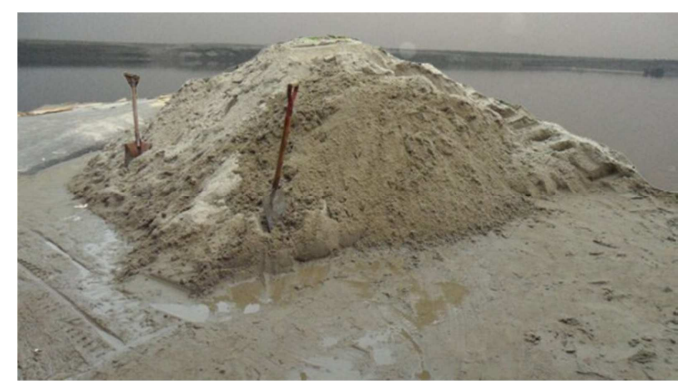

Figure 1. Source of fine sand.

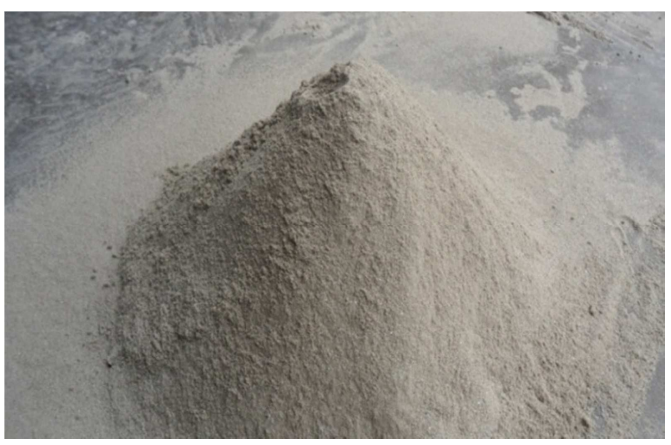

Figure 2. Physical appearance of fine sand.

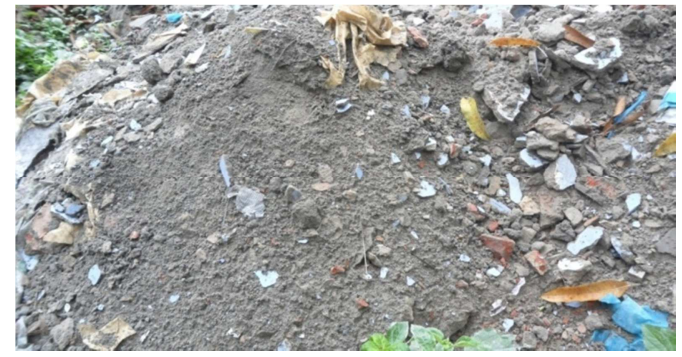

Figure 3. Source of construction debris.

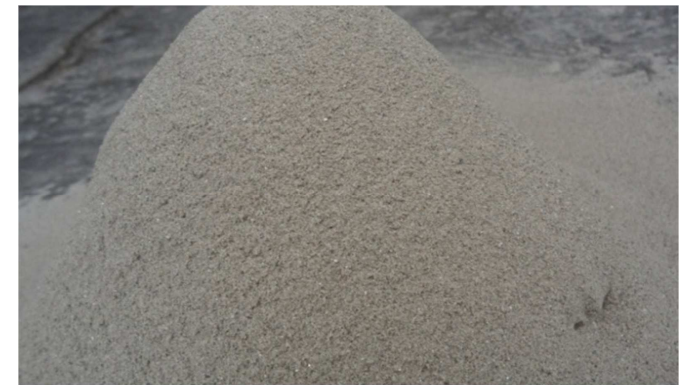

Figure 4. Construction debris after passing through $600 \mu \mathrm{m}$ sieve.

3.2. Laboratory Tests for the Properties of Materials (Fine Sand and Construction Debris) 
The test were performed to determine the compacted unit weight, specific gravity, fineness modulus (FM), gradation, optimum moisture content (OMC) and maximum dry density according to the procedure specified by ASTM standard. The results are summarized in Table 1, Grain size analysis data of fine sand is given in Table 2, and the curve is shown in Figure 5.

Table 1. Properties of fine sand and construction debris.

\begin{tabular}{llllll}
\hline Sample & $\begin{array}{l}\text { Dense unit weight } \\
\left(\mathbf{K g} / \mathbf{m}^{\mathbf{3}}\right)\end{array}$ & Specific gravity & $\begin{array}{l}\text { Fineness modulus } \\
(\mathbf{F M})\end{array}$ & $\begin{array}{l}\text { Optimum moisture content } \\
(\mathbf{\%})\end{array}$ & $\begin{array}{l}\text { Maximum dry } \\
\text { density }(\mathbf{g m} / \mathbf{c c})\end{array}$ \\
\hline Fine sand & 1132.25 & 2.62474 & 1.64 & 16.5 \\
Construction debris & 1273.44 & 2.43268 & 1.36 & 1.50 \\
\hline
\end{tabular}

Table 2. Grain-size analysis of construction debris and fine sand.

\begin{tabular}{lll}
\hline \multirow{2}{*}{ Sieve size, $\mathbf{m m}$} & \% Passing & \\
\cline { 2 - 3 } & Construction debris & Fine sand \\
\hline 4.75 & 100 & 100 \\
2.36 & 100 & 100 \\
1.70 & 100 & 100 \\
1.18 & 100 & 100 \\
0.60 & 99.6 & 98.4 \\
0.30 & 87.6 & 78.8 \\
0.212 & 58 & 39.3 \\
0.150 & 18.4 & 19.62 \\
0.075 & 0.8 & 1.22 \\
\hline
\end{tabular}

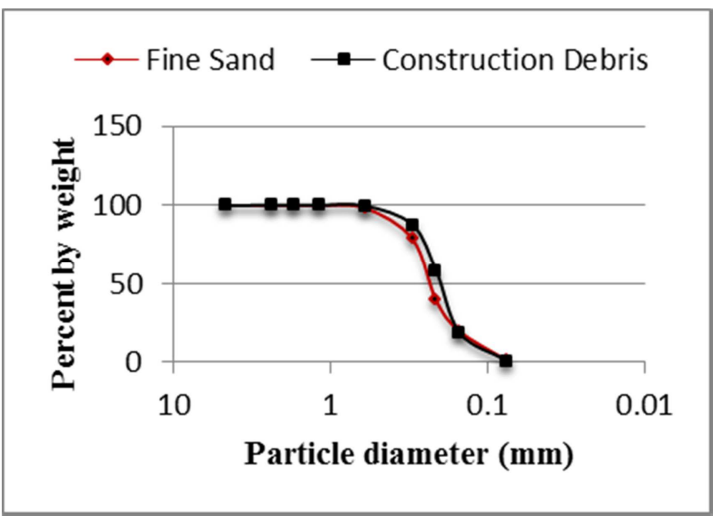

Figure 5. Grain size distribution curves of fine sand and construction debris.

\subsection{Testing Set-up Apparatus}

In this study, compaction testing and CBR testing setup were used. In the testing setup Compaction

Mould and Rammer, Balance and Steel Straight Edge, CBR Test Apparatus were included. The following Figure 6, Figure 7, Figure 8 respectively are shown the equipments.

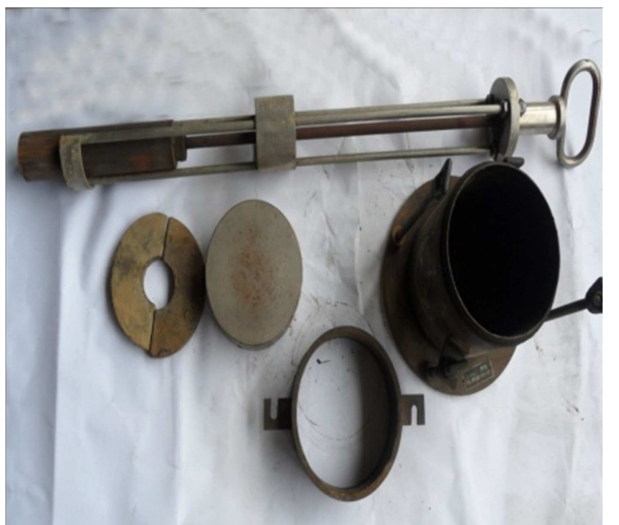

Figure 6. Compaction mould and rammer.

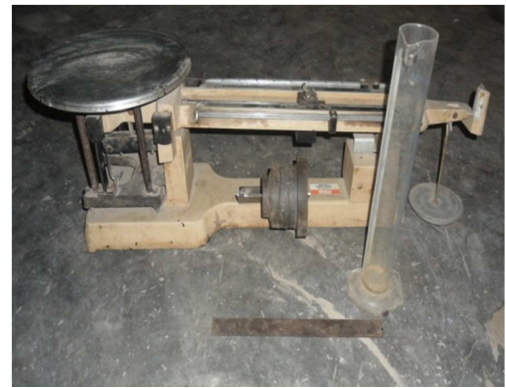

Figure 7. Balance, straight edge and measuring cylinder.

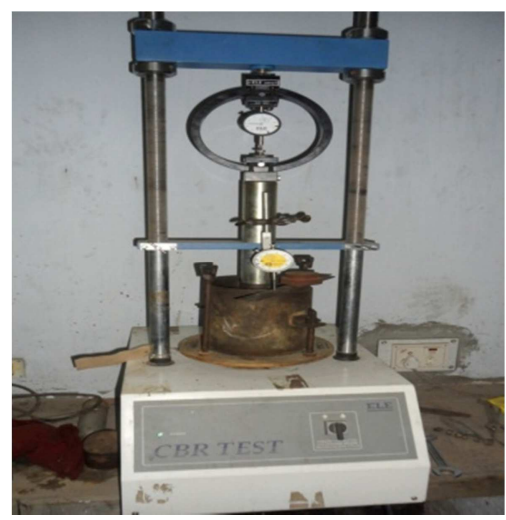

Figure 8. CBR testing apparatus.

\subsection{Experimental Program}

In the study, fine sand and construction debris were used to investigate the CBR characteristics of sub grade at different soaking period. The following programs were fixed up for the investigation program.

\subsubsection{Testing Procedure}

The mould with the specimen was clamped over the base plate and same surcharge weights of $2.5 \mathrm{~kg}$ were placed on the specimen centrally such that the penetration test could be conducted. The mould with base plate was placed under the penetration plunger $(5 \mathrm{~cm}$ diameter) of the loading machine (Figure 8). The penetration plunger was placed at the center of the specimen and was brought in contact with the top surface of the sample by applying a seating load of $4.0 \mathrm{~kg}$. The dial gauge for measuring the penetration value of the plunger was fitted in position. The dial gauge of the proving ring and the penetration dial gauge were set to zero. The load was applied through the penetration plunger at a uniform rate of $1.25 \mathrm{~kg} / \mathrm{min}$. The load readings were recorded at penetration readings of $0.0,0.5,1.0,1.5,2.0,2.5,3.0,4.0,5.0$, $7.5,10.0$ and $12.5 \mathrm{~mm}$. In case the load readings starts 
decreasing before $12.5 \mathrm{~mm}$ penetration the maximum load value and the corresponding penetration value were recorded. After the final reading, the load was released and the mould was removed from the loading machine. The proving ring load calibration chart was noted so that the load dial values can be converted into load in $\mathrm{kg}$. About $50 \mathrm{gm}$. of soil was collected from the top three $\mathrm{cm}$ depth of the soil sample for the determination of moisture content.

\subsubsection{Determination of Swelling}

The swelling or expansion ratio is calculated from the observations during the swelling test using the formula:

$$
\text { Expansion ratio }(\%)=\frac{\left(d_{f}-d_{i}\right)}{h} \times 100
$$

Where,

$\mathrm{d}_{\mathrm{f}}=$ Final dial gauge reading after soaking, $\mathrm{mm}$

$\mathrm{d}_{\mathrm{i}}=$ Initial gauge reading after soaking, $\mathrm{mm}$

$\mathrm{h}=$ Initial height of specimen, $\mathrm{mm}$

Table 3. Swelling or expansion value for different soaking period of fine sand and construction debris.

\begin{tabular}{lll}
\hline $\begin{array}{l}\text { Soaking period } \\
\text { (hours) }\end{array}$ & Swelling (\%) & \\
\cline { 2 - 3 } & Fine sand & Construction debris \\
\hline 24 & 0.06604 & 0.43180 \\
48 & 0.08128 & 0.09652 \\
72 & 0.09652 & 0.10668 \\
96 & 0.13716 & 0.17272 \\
\hline
\end{tabular}

\subsubsection{Determination of CBR Value}

The load values noted for each penetration level are divided by the area of the loading plunger $(19.635 \mathrm{sq} .-\mathrm{cm})$ to obtain the pressure or unit load values on the loading plunger and the results are summarized in Table 4, Table 5 and Table 6.

Table 4represents the unit load values for un-soaked condition for both fine sand and construction debris and Table 5 and Table 6 represent the unit load values for soaked condition of fine sand and construction debris respectively. From Table 4 the load-penetration curves are then plotted in natural scale for both sample for un-soaked condition as shown in Figure 9 and Figure 10. From Table 5 the loadpenetration curves are then plotted in natural scale for Fine sand for different soaking period as shown in Figure 11, Figure 12, Figure 13 and Figure 14. From Table 6 the loadpenetration curves are then plotted in natural scale for construction debris for different soaking period as shown in Figure 15, Figure 16, Figure 17 and Figure 18. If the curve is uniformly convex upwards no correction is needed. In case there is a reverse curve or the initial portion of the curves concave upwards necessity of a correction is indicated. A tangent is drawn from the steepest point on the curve to intersect the base at a point, which is the corrected origin corresponding to zero penetration.

Table 4. Penetration and corresponding unit load for un-soaked condition of fine sand and construction debris.

\begin{tabular}{lllll}
\hline Sample & Fine sand & \multicolumn{2}{l}{ Construction debris } \\
\hline \multirow{2}{*}{ Penetration $\mathbf{( m m )})$} & \multicolumn{3}{l}{ Unit load $\left.\mathbf{( K g} / \mathbf{c m}^{\mathbf{2}}\right)$} & Sp-II \\
\cline { 2 - 5 } & Spit load $\left.\mathbf{( K g} / \mathbf{c m}^{\mathbf{2}}\right)$ & Sp-II & Sp-I & 0 \\
\hline 0.0 & 0 & 0 & 0 & 0.756 \\
0.5 & 1.385 & 1.259 & 1.008 & 2.015 \\
1.0 & 3.275 & 2.771 & 2.645 & 3.652 \\
1.5 & 5.668 & 4.786 & 4.534 & 5.542 \\
2.0 & 7.557 & 6.801 & 6.297 & 6.927 \\
2.5 & 8.816 & 8.564 & 7.557 & 8.061 \\
3.0 & 9.698 & 10.202 & 8.564 & 9.572 \\
4.0 & 11.209 & 12.091 & 9.824 & 10.328 \\
5.0 & 12.091 & 12.973 & 10.454 & 11.335 \\
7.5 & 13.476 & 13.602 & 11.083 & 11.965 \\
10.0 & 14.106 & 14.232 & 11.713 & 12.595 \\
\hline
\end{tabular}

Table 5. Penetration and corresponding unit load for soaked condition of fine sand.

\begin{tabular}{|c|c|c|c|c|c|c|c|c|}
\hline \multirow{3}{*}{ Penetration (mm) } & \multirow{2}{*}{\multicolumn{2}{|c|}{$\begin{array}{l}24 \mathrm{hr} . \text { soaked } \\
\text { Unit load }\left(\mathrm{Kg} / \mathrm{cm}^{2}\right)\end{array}$}} & \multirow{2}{*}{\multicolumn{2}{|c|}{$\begin{array}{l}48 \mathrm{hr} \text {. soaked } \\
\text { Unit load }\left(\mathrm{Kg} / \mathrm{cm}^{2}\right)\end{array}$}} & \multirow{2}{*}{\multicolumn{2}{|c|}{$\begin{array}{l}72 \text { hr. soaked } \\
\text { Unit load }\left(\mathrm{Kg} / \mathrm{cm}^{2}\right)\end{array}$}} & \multirow{2}{*}{\multicolumn{2}{|c|}{$\begin{array}{l}96 \text { hr. soaked } \\
\text { Unit load }\left(\mathrm{Kg} / \mathrm{cm}^{2}\right)\end{array}$}} \\
\hline & & & & & & & & \\
\hline & Sp-I & Sp-II & Sp-I & Sp-II & Sp-I & Sp-II & Sp-I & Sp-II \\
\hline 0.0 & 0 & 0 & 0 & 0 & 0 & 0 & 0 & 0 \\
\hline 0.5 & 1.008 & 0.630 & 0.882 & 0.630 & 1.134 & 0.756 & 0.630 & 1.008 \\
\hline 1.0 & 2.267 & 1.763 & 2.519 & 2.015 & 2.267 & 1.889 & 1.511 & 2.015 \\
\hline 1.5 & 3.778 & 3.275 & 3.778 & 3.401 & 3.275 & 3.023 & 2.645 & 2.897 \\
\hline 2.0 & 5.038 & 4.786 & 4.786 & 4.408 & 4.030 & 3.778 & 3.652 & 3.527 \\
\hline 2.5 & 6.045 & 5.794 & 5.542 & 5.164 & 4.660 & 4.408 & 4.282 & 4.156 \\
\hline 3.0 & 6.801 & 6.549 & 6.171 & 5.794 & 5.164 & 4.912 & 4.786 & 4.660 \\
\hline 4.0 & 7.935 & 7.683 & 7.179 & 6.801 & 5.920 & 5.668 & 5.668 & 5.416 \\
\hline 5.0 & 8.564 & 8.313 & 7.809 & 7.431 & 6.549 & 6.297 & 6.171 & 5.920 \\
\hline 7.5 & 9.446 & 9.320 & 8.564 & 8.313 & 7.305 & 7.179 & 7.179 & 6.927 \\
\hline 10.0 & 9.698 & 9.950 & 8.942 & 8.690 & 7.683 & 7.683 & 7.809 & 7.557 \\
\hline 12.0 & 9.950 & 10.202 & 9.194 & 8.942 & 8.061 & 7.935 & 8.187 & 7.935 \\
\hline
\end{tabular}


Table 6. Penetration and corresponding unit load for soaked condition of construction debris.

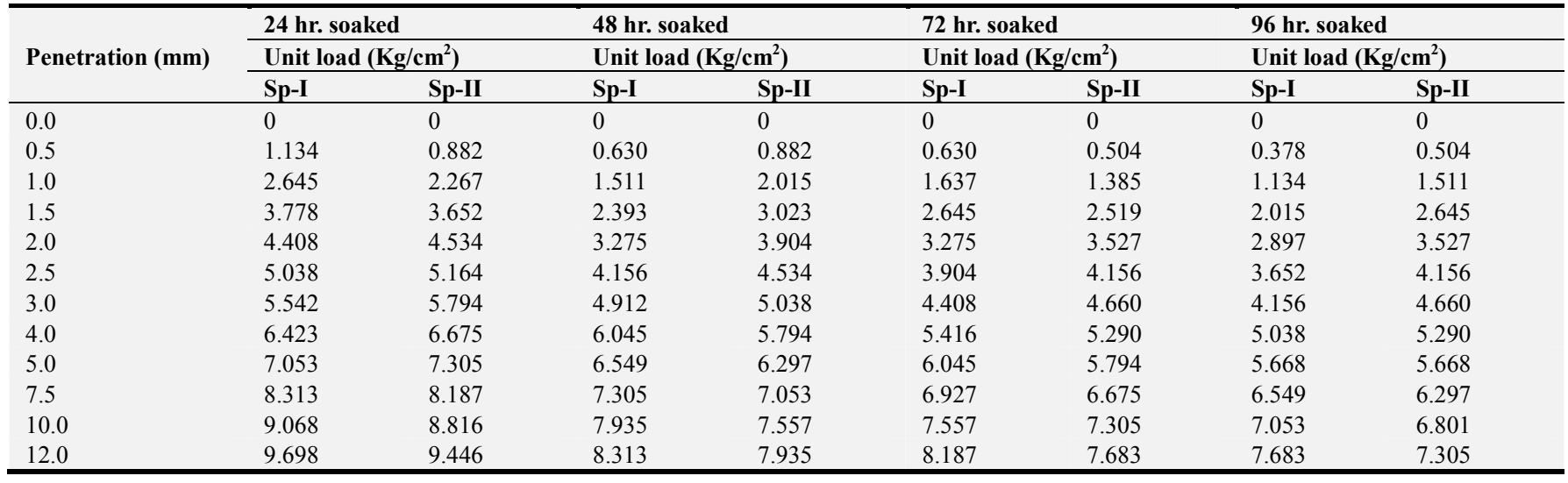

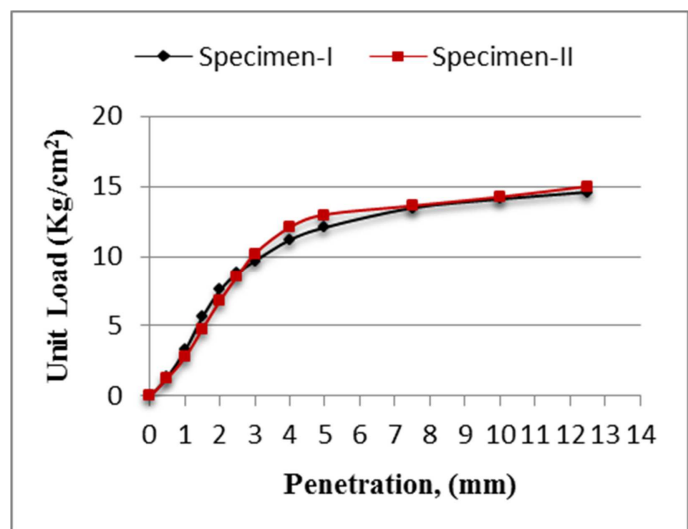

Figure 9. Unit load-penetration curve for fine sand (un-soaked).

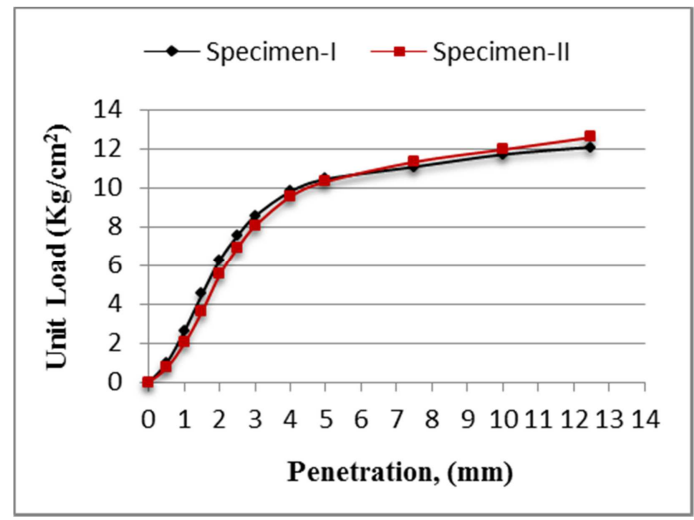

Figure 10. Unit load-penetration curve for construction debris (un-soaked).

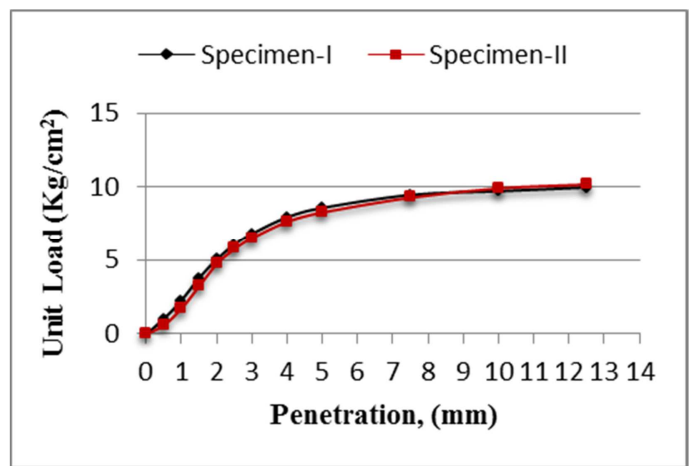

Figure 11. Unit load-penetration curve for fine sand (24 hr. soaked).

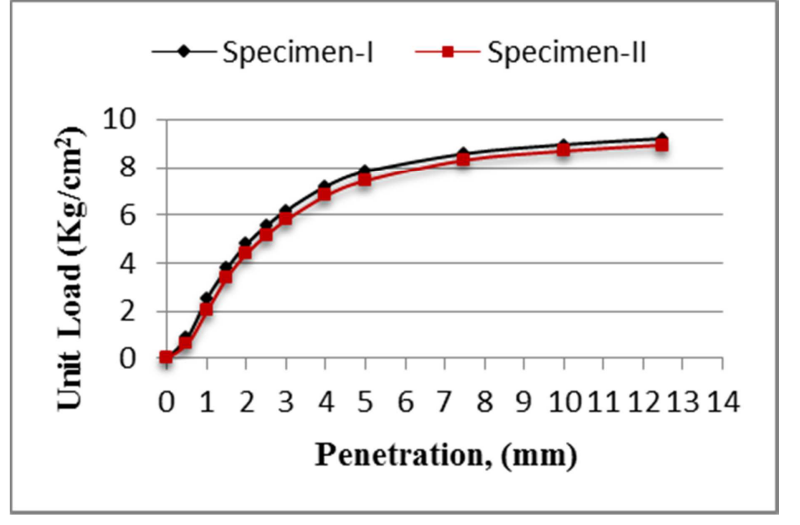

Figure 12. Unit load-penetration curve for fine sand (48 hr. soaked).

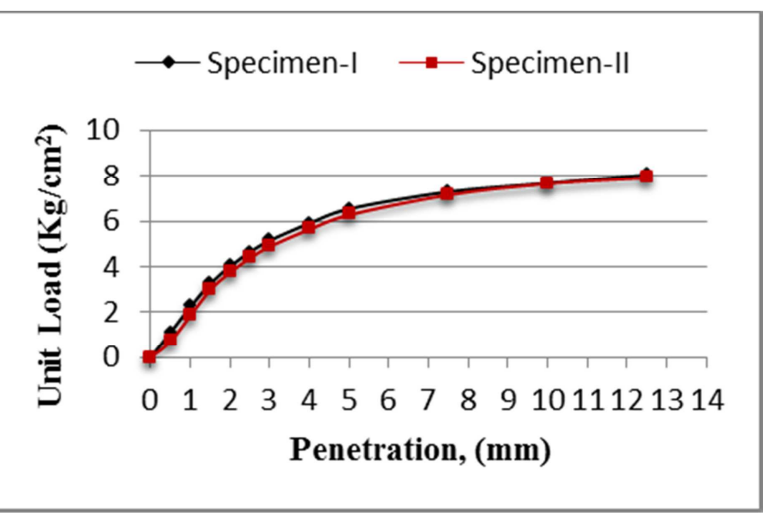

Figure 13. Unit load-penetration curve for fine sand (72 hr. soaked).

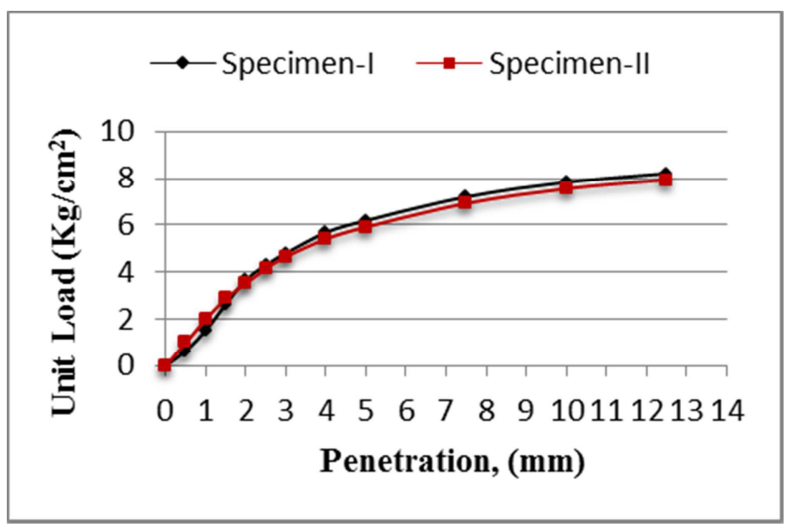

Figure 14. Unit load-penetration curve for fine sand (96 hr. soaked). 


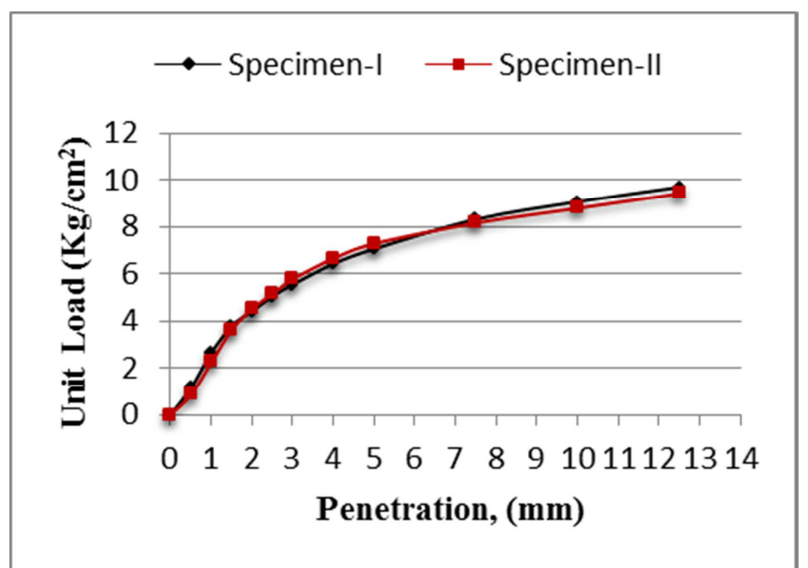

Figure 15. Unit load-penetration curve for construction debris $(24 \mathrm{hr}$. soaked).

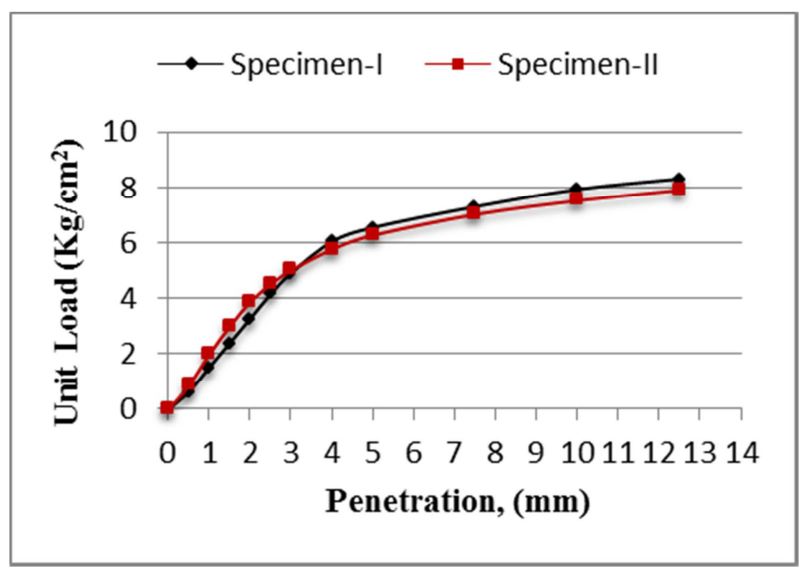

Figure 16. Unit load-penetration curve for construction debris (48 hr. soaked).

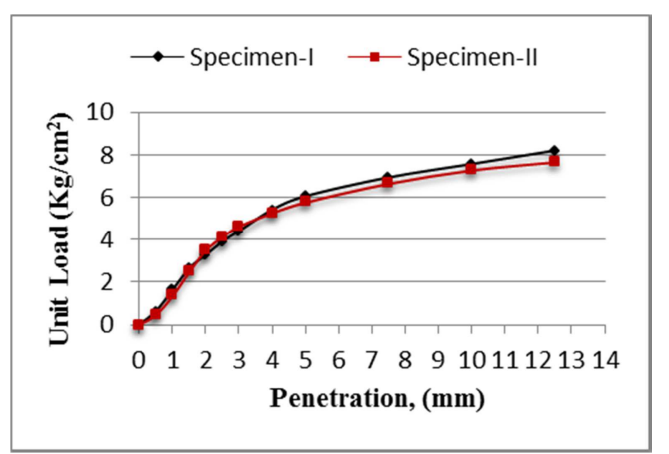

Figure 17. Unit load-penetration curve for construction debris $(72 \mathrm{hr}$. soaked).

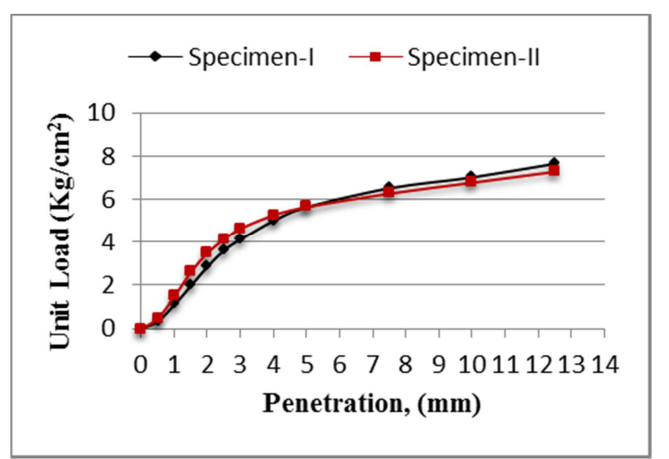

Figure 18. Unit load-penetration curve for construction debris $(96 \mathrm{hr}$ : soaked).

The unit load values corresponding to $2.50 \mathrm{~mm}$ and 5.0 $\mathrm{mm}$ penetration values are found from graphs and recorded in Table 7 and Table 8 for fine sand and construction debris respectively.

The CBR value is calculated from this formula:

$$
\operatorname{CBR}(\%)=\frac{\text { Unit load carried by soil sample at defined penetration level }}{\text { Unit load carried by standard crushed stone at above penetration level }} \times 100
$$

The unit load values on standard crushed stones are 70 $\mathrm{kg} / \mathrm{cm}^{2}$ and $105 \mathrm{~kg} / \mathrm{cm}^{2}$ for $2.5 \mathrm{~mm}$ and $5.0 \mathrm{~mm}$ penetration respectively. The CBR values at $2.5 \mathrm{~mm}$ and $5.0 \mathrm{~mm}$ penetration are calculated for each sample from corresponding graphs and recorded in Table 9 to Table 10. Generally the CBR value at $2.5 \mathrm{~mm}$ penetration is higher and this value is adopted. However if higher value is obtained at $5.0 \mathrm{~mm}$ penetration, the test is to be repeated to verify the results; if the value at $5.0 \mathrm{~mm}$ penetration is again higher, this is adopted as the CBR value of the sample. \% CBR values for different soaking period of fine sand and construction debris are summarized in Table 11.

Table 7. Unit load values corresponding to $2.5 \mathrm{~mm}$ and $5.0 \mathrm{~mm}$ penetration for different soaking period for fine sand.

\begin{tabular}{|c|c|c|c|c|c|c|c|c|c|c|c|}
\hline \multirow[b]{2}{*}{$\begin{array}{l}\text { Penetration } \\
(\mathrm{mm})\end{array}$} & \multirow[b]{2}{*}{ Specimen } & \multicolumn{2}{|l|}{ Un-soak } & \multicolumn{2}{|c|}{24 hr. Soaking } & \multicolumn{2}{|c|}{48 hr. Soaking } & \multicolumn{2}{|c|}{ 72hr. Soaking } & \multicolumn{2}{|c|}{96 hr. Soaking } \\
\hline & & $\begin{array}{l}\text { Unit load } \\
\left(\mathrm{Kg} / \mathrm{cm}^{2}\right)\end{array}$ & $\% \mathrm{CBR}$ & $\begin{array}{l}\text { Unit load } \\
\left(\mathrm{Kg} / \mathrm{cm}^{2}\right)\end{array}$ & $\% \mathrm{CBR}$ & $\begin{array}{l}\text { Unit load } \\
\left(\mathrm{Kg} / \mathrm{cm}^{2}\right)\end{array}$ & $\% \mathrm{CBR}$ & $\begin{array}{l}\text { Unit load } \\
\left(\mathrm{Kg} / \mathrm{cm}^{2}\right)\end{array}$ & $\%$ CBR & $\begin{array}{l}\text { Unit load } \\
\left(\mathrm{Kg} / \mathrm{cm}^{2}\right)\end{array}$ & $\%$ CBR \\
\hline \multirow{2}{*}{2.5} & Sp-I & 9 & 12.86 & 6.5 & 9.29 & 5 & 7.14 & 4.25 & 6.07 & 4.5 & 6.43 \\
\hline & $\mathrm{Sp}-\mathrm{II}$ & 8.5 & 12.14 & 6 & 8.57 & 5.5 & 7.86 & 5 & 7.14 & 4 & 5.71 \\
\hline \multirow{2}{*}{5.0} & $\mathrm{Sp}-\mathrm{I}$ & 12 & 11.43 & 8.5 & 8.10 & 8 & 7.62 & 6.5 & 6.19 & 6 & 5.71 \\
\hline & Sp-II & 12.5 & 11.90 & 8 & 7.62 & 7.5 & 7.14 & 6.5 & 6.19 & 6.5 & 6.19 \\
\hline
\end{tabular}

Table 8. Unit load values corresponding to $2.5 \mathrm{~mm}$ and $5.0 \mathrm{~mm}$ penetration for different soaking period for construction debris.

\begin{tabular}{|c|c|c|c|c|c|c|c|c|c|c|c|}
\hline \multirow[b]{2}{*}{$\begin{array}{l}\text { Penetration } \\
(\mathbf{m m})\end{array}$} & \multirow[b]{2}{*}{ Specimen } & \multicolumn{2}{|l|}{ Un-soak } & \multicolumn{2}{|c|}{24 hr. Soaking } & \multicolumn{2}{|c|}{48 hr. Soaking } & \multicolumn{2}{|c|}{ 72hr. Soaking } & \multicolumn{2}{|c|}{96 hr. Soaking } \\
\hline & & $\begin{array}{l}\text { Unit load } \\
\left(\mathrm{Kg} / \mathrm{cm}^{2}\right)\end{array}$ & $\%$ CBR & $\begin{array}{l}\text { Unit load } \\
\left(\mathrm{Kg} / \mathrm{cm}^{2}\right)\end{array}$ & $\begin{array}{l}\% \\
\text { CBR } \\
\end{array}$ & $\begin{array}{l}\text { Unit load } \\
\left(\mathrm{Kg} / \mathrm{cm}^{2}\right)\end{array}$ & $\begin{array}{l}\% \\
\text { CBR } \\
\end{array}$ & $\begin{array}{l}\text { Unit load } \\
\left(\mathrm{Kg} / \mathrm{cm}^{2}\right) \\
\end{array}$ & $\begin{array}{l}\% \\
\text { CBR } \\
\end{array}$ & $\begin{array}{l}\text { Unit load } \\
\left(\mathrm{Kg} / \mathrm{cm}^{2}\right) \\
\end{array}$ & $\begin{array}{l}\% \\
\text { CBR } \\
\end{array}$ \\
\hline \multirow{2}{*}{2.5} & $\mathrm{Sp}-\mathrm{I}$ & 7.5 & 10.71 & 5 & 7.14 & 4.5 & 6.43 & 4 & 5.71 & 3.5 & 5.00 \\
\hline & $\mathrm{Sp}-\mathrm{II}$ & 7 & 10.00 & 5.5 & 7.86 & 4 & 5.71 & 4 & 5.71 & 4 & 5.71 \\
\hline 5.0 & Sp-I & 10.5 & 10.00 & 7 & 6.67 & 6.5 & 6.19 & 5.5 & 5.24 & 5 & 4.76 \\
\hline
\end{tabular}




\begin{tabular}{|c|c|c|c|c|c|c|c|c|c|c|c|}
\hline \multirow[b]{2}{*}{$\begin{array}{l}\text { Penetration } \\
(\mathrm{mm})\end{array}$} & \multirow[b]{2}{*}{ Specimen } & \multicolumn{2}{|l|}{ Un-soak } & \multicolumn{2}{|c|}{24 hr. Soaking } & \multicolumn{2}{|c|}{48 hr. Soaking } & \multicolumn{2}{|c|}{ 72hr. Soaking } & \multicolumn{2}{|c|}{96 hr. Soaking } \\
\hline & & $\begin{array}{l}\text { Unit load } \\
\left(\mathrm{Kg} / \mathrm{cm}^{2}\right)\end{array}$ & $\%$ CBR & $\begin{array}{l}\text { Unit load } \\
\left(\mathrm{Kg} / \mathrm{cm}^{2}\right)\end{array}$ & $\begin{array}{l}\text { \% } \\
\text { CBR }\end{array}$ & $\begin{array}{l}\text { Unit load } \\
\left(\mathrm{Kg} / \mathrm{cm}^{2}\right)\end{array}$ & $\begin{array}{l}\% \\
\text { CBR }\end{array}$ & $\begin{array}{l}\text { Unit load } \\
\left(\mathrm{Kg} / \mathrm{cm}^{2}\right)\end{array}$ & $\begin{array}{l}\% \\
\text { CBR }\end{array}$ & $\begin{array}{l}\text { Unit load } \\
\left(\mathrm{Kg} / \mathrm{cm}^{2}\right)\end{array}$ & $\begin{array}{l}\% \\
\text { CBR }\end{array}$ \\
\hline & Sp-II & 10.5 & 10.00 & 7.5 & 7.14 & 6.5 & 6.19 & 6.25 & 5.95 & 5.5 & 5.24 \\
\hline
\end{tabular}

Table 9. CBR value for different soaking period of fine sand.

\begin{tabular}{|c|c|c|c|c|c|c|}
\hline \multirow{3}{*}{ Penetration (mm) } & \multirow{3}{*}{ Specimen } & \multicolumn{5}{|c|}{ CBR (\%) } \\
\hline & & \multicolumn{5}{|c|}{ Soaking period } \\
\hline & & o hr. & $24 \mathrm{hr}$. & $48 \mathrm{hr}$. & $72 \mathrm{hr}$. & $96 \mathrm{hr}$. \\
\hline \multirow{3}{*}{2.5} & Sp-I & 12.86 & 9.29 & 7.14 & 6.07 & 6.43 \\
\hline & Sp-II & 12.14 & 8.57 & 7.86 & 7.14 & 5.71 \\
\hline & Average & 12.50 & 8.93 & 7.50 & 6.61 & 6.07 \\
\hline \multirow{3}{*}{5.0} & Sp-I & 11.43 & 8.10 & 7.62 & 6.19 & 5.71 \\
\hline & Sp-II & 11.90 & 7.62 & 7.14 & 6.19 & 6.19 \\
\hline & Average & 11.67 & 7.86 & 7.38 & 6.19 & 5.95 \\
\hline
\end{tabular}

Table 10. CBR value for different soaking period of construction debris.

\begin{tabular}{|c|c|c|c|c|c|c|}
\hline \multirow{3}{*}{ Penetration (mm) } & \multirow{3}{*}{ Specimen } & \multicolumn{5}{|c|}{ CBR (\%) } \\
\hline & & \multicolumn{5}{|c|}{ Soaking period } \\
\hline & & o hr. & $24 \mathrm{hr}$. & $48 \mathrm{hr}$. & $72 \mathrm{hr}$. & $96 \mathrm{hr}$. \\
\hline \multirow{3}{*}{2.5} & Sp-I & 10.71 & 7.14 & 6.43 & 5.71 & 5.00 \\
\hline & Sp-II & 10.00 & 7.86 & 5.71 & 5.71 & 5.71 \\
\hline & Average & 10.36 & 7.50 & 6.19 & 5.71 & 5.36 \\
\hline \multirow{3}{*}{5.0} & Sp-I & 10.00 & 6.67 & 6.19 & 5.24 & 4.76 \\
\hline & Sp-II & 10.00 & 7.14 & 6.19 & 5.95 & 5.24 \\
\hline & Average & 10 & 6.90 & 6.19 & 5.24 & 5.00 \\
\hline
\end{tabular}

Table 11. \% CBR value for different soaking period of fine sand and construction debris.

\begin{tabular}{llllll}
\hline \multirow{2}{*}{ Sample } & \% CBR & & & \\
\cline { 2 - 6 } & 0 hr. soaked & $\mathbf{2 4} \mathbf{~ h r}$ soaked & $\mathbf{4 8} \mathbf{~ h r}$ soaked & $\mathbf{7 2}$ hr. soaked & $\mathbf{9 6} \mathbf{~ h r}$ soaked \\
\hline Fine sand & 12.50 & 8.93 & 7.50 & 6.61 & 6.07 \\
Construction debris & 10.36 & 7.50 & 6.19 & 5.71 & 5.36 \\
\hline
\end{tabular}

\section{Results and Discussions}

\subsection{General}

In this chapter, the experimental test results are presented. The properties of selected materials and behavior of construction debris on CBR value are discussed. The effects of soaking period on the CBR value of construction debris are also presented.

\subsection{Properties of Selected Materials}

The dense unit weight, specific gravity and fineness modulus of selected materials are presented in Table 12 .

\subsection{CBR Characteristics of Construction Debris}

The CBR values of Fine sand and Construction Debris for un-soaked condition are given in Table 13.

\subsection{Effect of Soaking Period on the CBR Value}

The relationship between CBR and soaking period for selected samples are shown in Figure 19.
Table 12. Compacted unit weight, specific gravity and fineness modulus of fine sand and construction debris.

\begin{tabular}{llll}
\hline Sample & $\begin{array}{l}\text { Dense unit } \\
\text { weight }\left(\mathbf{K g} / \mathbf{m}^{\mathbf{3}}\right)\end{array}$ & $\begin{array}{l}\text { Specific } \\
\text { gravity }\end{array}$ & $\begin{array}{l}\text { Fineness } \\
\text { modulus }\end{array}$ \\
\hline Fine sand & 1132.25 & 2.62474 & 1.64 \\
Construction debris & 1273.44 & 2.43268 & 1.36 \\
\hline
\end{tabular}

Table 13. CBR values of fine sand and construction debris for un-soaked condition.

\begin{tabular}{lll}
\hline Types of materials & \% CBR & Limiting value* \\
\hline Fine sand & 12.50 & 5 \\
Construction debris & 10.36 & 5 \\
\hline
\end{tabular}

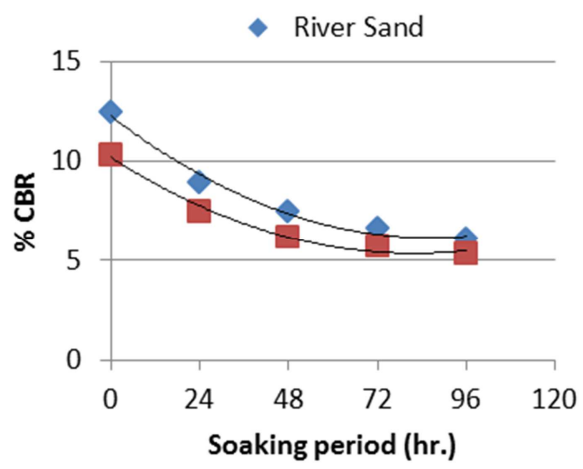

Figure 19. Relationship between CBR value and soaking period. 


\section{Conclusions}

On the basis of experimental results of this study, it can be recapitulated that waste dust passing through $600 \mu \mathrm{m}$ sieve from construction debris is suitable as sub-grade soil from the consideration of physical properties. Un-soaked and soaked CBR value of construction debris are $10.36 \%$ and $5.36 \%$ which are very close to the respective value $12.50 \%$ and $6.07 \%$ of fine sand. CBR value decreases with the increase of soaking period. This variation for construction debris is similar for fine sand.

\section{References}

[1] Arulrajah, A., Piratheepan, J., Disfani, M. M., \& Bo, M. W. (2012). Geotechnical and geo-environmental properties of recycled construction and demolition materials in pavement sub-base applications. Journal of Materials in Civil Engineering, 25 (8), 1077-1088.

[2] Arulrajah, A., Disfani, M. M., Horpibulsuk, S., Suksiripattanapong, C., \&Prongmanee, N. (2014). Physical properties and shear strength responses of recycled construction and demolition materials in unbound pavement base/subbase applications. Construction and Building Materials, 58, 245-257.

[3] Barbudo, A., Agrela, F., Ayuso, J., Jiménez, J. R., \& Poon, C. S. (2012). Statistical analysis of recycled aggregates derived from different sources for sub-base applications. Construction and Building Materials, 28 (1), 129-138.

[4] deRezende, L. R., \& de Carvalho, J. C. (2003). The use of quarry waste in pavement construction. Resources, conservation and recycling, 39 (1), 91-105.

[5] Gobieanandh, V., \& Jayakody, S. (2016). Evaluate the strength of cement treated recycled construction and demolition aggregates as a pavement material. In 7th International Conference on Sustainable Built Environment (pp. 62-67).

[6] Herrador, R., Pérez, P., Garach, L., \& Ordóñez, J. (2011). Use of recycled construction and demolition waste aggregate for road course surfacing. Journal of Transportation Engineering, 138 (2), 182-190.

[7] Vegas, I., Ibañez, J. A., Lisbona, A., De Cortazar, A. S., \& Frías, M. (2011). Pre-normative research on the use of mixed recycled aggregates in unbound road sections. Construction and Building Materials, 25 (5), 2674-2682.
[8] Sabat, A. K. (2012). Stabilization of expansive soil using waste ceramic dust. Electronic Journal of Geotechnical Engineering, 17 (Bund. Z).

[9] Pedro, D., De Brito, J., \& Evangelista, L. (2014). Influence of the use of recycled concrete aggregates from different sources on structural concrete. Construction and Building Materials, 71, 141-151.

[10] daConceiçãoLeite, F., dos Santos Motta, R., Vasconcelos, K. L., \& Bernucci, L. (2011). Laboratory evaluation of recycled construction and demolition waste for pavements Construction and Building Materials, 25 (6), 2972-2979.

[11] Vipulanandan, C., Basheer, M., \& O’Neill, M. (1996). Recycled materials in embankments, except glass. The Center for Innovative Grouting Materials and Technology Research Report 0-1351, Preliminary Report, Houston, Texas.

[12] Robinson Jr, G. R., Menzie, W. D., \& Hyun, H. (2004). Recycling of construction debris as aggregate in the MidAtlantic Region, USA. Resources, Conservation and Recycling, 42 (3), 275-294.

[13] Silva, R. V., De Brito, J., \& Dhir, R. K. (2014). Properties and composition of recycled aggregates from construction and demolition waste suitable for concrete production. Construction and Building Materials, 65, 201-217.

[14] Rahman, M. A., Imteaz, M., Arulrajah, A., \& Disfani, M. M. (2014). Suitability of recycled construction and demolition aggregates as alternative pipe backfilling materials. Journal of Cleaner Production, 66, 75-84.

[15] Pepe, M., Toledo Filho, R. D., Koenders, E. A., \& Martinelli, E. (2014). Alternative processing procedures for recycled aggregates in structural concrete. Construction and Building Materials, 69, 124-132.

[16] Ossa, A., García, J. L., \& Botero, E. (2016). Use of recycled construction and demolition waste (CDW) aggregates: a sustainable alternative for the pavement construction industry. Journal of Cleaner Production, 135, 379-386.

[17] Pérez, P., Agrela, F., Herrador, R., \& Ordoñez, J. (2013). Application of cement-treated recycled materials in the construction of a section of road in Malaga, Spain. Construction and Building Materials, 44, 593-599.

[18] Huang, Y., Bird, R. N., \& Heidrich, O. (2007). A review of the use of recycled solid waste materials in asphalt pavements. Resources, conservation and recycling, 52 (1), 58-73. 